\title{
FULL DAY SCHOOL DALAM PEMBENTUKAN KARAKTER SISWA SMKN13 KOTA MALANG
}

\author{
Marleny Leasa ${ }^{1}$, John Rafafy Batlolona ${ }^{2}$ \\ ${ }^{1}$ Pendidikan Guru Sekolah Dasar - FKIP, Universitas Pattimura \\ Ambon, Indonesia \\ ${ }^{2}$ Pascasarjana Pendidikan Fisika, Universitas Negeri Malang, \\ Malang, Indonesia \\ e-mail: marleny.leasa@yahoo.com
}

\begin{abstract}
Abstrak
Pendidikan dengan kualitas yang bermartabat dan baik dimulai dari terbentuknya karakter mulia peserta didik. Penelitian bertujuan untuk mendeskripsikan pembinaan dan pembentukan karakter siswa (taruna) jurusan keperawatan di SMK Negeri 13 Malang. Penelitian menggunakan statistik deskriptif, untuk mengungkap respon sekolah terhadap program Full Day School(FDS) dalam rangka pembinaan dan pembentukan karakter siswa. Hasil penelitian menunjukkan bahwa respon sekolah (kepala sekolah, guru pembina) termasuk dalam kategori sangat baik, sedangkan instruktur TNI AL termasuk dalam kategori baik. Perolehan nilai karakter keperawatan siswakelas $\mathrm{X}$ yaitu $13,63 \%$ kategori memuaskan; 31,82\%kategori sangat baik; dan $54,54 \%$ kategori baik. Dengan demikian disimpulkan bahwa sekolah dan siswa samasama memberikan respon yang positif terhadap kegiatan FDS. Penelitian selanjutnya disarankan untuk memperoleh informasi tentang output karakter lulusan di dunia kerja atau di masyarakat.
\end{abstract}

Kata kunci : full day school, karakter, peserta didik

\begin{abstract}
Education with dignity and good quality starts from the formation of a noble character learners. This study aims to describe the development and character formation of student majoring in nursing at SMK Negeri 13 Kota Malang. Research using descriptive technique to uncover the response of FDS program in the framework of development and character formation of the student. The result showed that the response of the school (principals teachers) included in the very good category, while the Navy instructors included in good category. The character values of nursing students of class $X$ is $13,63 \%$ which is a statisfactory category; 31,82 as very good category; and 54,54 has good category. Thus concluded that the shcool and students a like responded positively to FDS activities. Future students recommended to obtain information about the character output of graduates in the workplace or in the community as an input to evaluate this program.
\end{abstract}

Keywords: full day school, character, student

\section{PENDAHULUAN}

Indonesiamemerlukan sumberdaya manusia yang memadai sebagai pilar utama dalam pembangunan nasional. Dalam kerangka itu, maka pendidikan formal (Pendidikan Sekolah) memiliki peran yang sangat penting. Pendidikan sekolah dalam domainnya sendiri, telah menjadi bagian tak terpisahkan dari kehidupansetiap orang (Hogan, 2006). Berdasarkan UU No 20 Tahun 2003 Tentang Sistem Pendidikan Nasional pada Pasal 3, yang menyebutkan bahwa pendidikan nasional berfungsi mengembangkan kemampuan dan membentuk karakter serta peradaban 
bangsa yang bermartabat dalam rangka mencerdaskan kehidupan bangsa. Bangsa yang besar memiliki kemampuan dan interaksi sosial yang baik. Interaksi sosial bertujuan membangun komunikasi antar ras, etnis, dan suku yang ada di daerah itu. Oleh karena itu membutuhkan karakter yang baik sehingga dapat beradaptasi dengan lingkungan sosialnya.Karakter dianggap sebagai bagian dari elemen psiko-sosial yang terkait dengan konteks sekitarnya (Koesoema, 2007).

Membangun karakter suatu bangsa membutuhkan waktu yang lama dan harus dilakukan secara berkesinambungan dan menyeluruh. Pemerintah Indonesia melalui Kementerian Pendidikan dan Kebudayaan periode yang baru tiada henti-hentinya melakukan upayauntuk perbaikan kualitas pendidikan di Indonesia, namun belum semuanya berhasil, terutama menghasilkan insan Indonesia yang berkarakter. Salah satu upaya untuk mewujudkan pendidikan yang seperti di atas, para peserta didik harus dibekali dengan pendidikan khusus yang membawa misi pokok dalam pembinaan karakter atau akhlak mulia (Qoyyimah, 2016).

Pendidikan karakter akan lebih bermakna jika dilakukan sejak usia dini. Pada usia dini 0-6 tahun, otak berkembang sangat pesat hingga 80 persen. Pada usia itu otak menerima dan menyerap berbagai macam informasi, baik dan buruk. Usia tersebut adalah periode di mana fisik, mental dan spiritual anak akan mulai terbentuk (Itstyarini, 2015). Oleh sebab itu penanaman nilai karakter di usia dini sangat penting sehingga anak ketika dewasa memiliki karakter dan integritas yang baik. Di sisi lain sejumlah mata pelajaran pendidikan telah diintegrasikan dalam sejumlah mata pelajaran dan masuk pada kegiatan inti (KI. 1 dan $\mathrm{KI} .2$ ), tetapi hal ini belum cukup. Sekolah yang merupakan motor penggerak pendidikan berupaya semaksimal mungkin agar peserta didik menjadi lebih baik.

Wacana pendidikan karakter di Indonesia menjadi headline utama dalam masyarakat pluralistik. Ciri masyarakat yang berkarakter antara lain cinta perdamaian, hidup harmoni, toleransi, integritas, rasa hormat, kerjasama, menghormati nilai-nilai, keyakinan, taat hukum, hubungan baik sesama sebagai warga negara (Sultana et al, 2008). Agustinova (2014) menyatakan bahwa pendidikan yang selama ini masih kelirudalam pengelolaan dan salah arah. Pendidikan saat ini belum mampu melahirkan pribadi-pribadi unggul, jujur, bertanggung jawab, berakhlak mulia, bertakwa, serta manusiawi. Kalaupun ada akan tetapi masih dalam jumlah yang sedikit. Penyimpangan arah ini menjadi hambatan dalam usaha mewujudkan pembangunan karakter bagi seluruh warga negara melalui pendidikan. Dunia pendidikan belum bisa memberikan alokasi yang memadai bagi tumbuhnya nilai-nilai kebajikan (virtues). Pendidikan hanya mampu melahirkan ahli ilmu pengetahuan (agama, matematika, biologi, fisika, kimia dan teknologi) tetapi miskin etika serta integritas.

Penyebab gagalnya pendidikan karakter di masyarakat khususnya masyarakat sekolah yaitu sekolah masih terbatas pada penyampaian moral knowing dan morang training, tetapi kurang menyentuh moral being, yaitu membiasakan anak untuk terus-menerus melakukan perbuatan moral. Sekolah harus memiliki kebijakan-kebijakan yang tepat untuk mengimplementasikan pendidikan karakter. Budimansyah \& Sapriya (2012) mengungkapkan untuk dapat berperilaku mandiri secara kontinue, salah satu hal yang perlu dikembangkan adalah adanya lingkungan sekolah kondusif. Pendidikan karakter adalah upaya yang dilakukan oleh pendidik untuk mengajarkan nilai-nilai moral kepada siswa. Inisiatif karakter telah diperkenalkan kembali di sekolah umum, dari jenjang SD hingga perguruan tinggi dalam menanggapi kekhawatiran tentang penurunan moral,keamanan sekolah, kohesi sosial, keterlibatan sipil, dan prestasi akademik (Winton, 2008).

Upaya untuk memaksimalkan kegiatan pembinaan karakter adalah dengan kegiatan full day school (FDS). Menteri Pendidikan dan Kebudayaan Republik Indonesia menyatakan bahwa, ada tiga alasan pemberlakuan kegiatan FDS antara lain, (1) Tidak ada mata 
pelajaran dengan pengertian FDS adalah pemberian jam tambahan. Tapi dalam jam tambahan tersebut tidak ada mata pelajaran yang bisa membuat para siswa bosan. Kegiatan yang dilakukan adalah ekstrakulikuler. Kegiatan ekstrakurikuler tersebut akan merangkum hingga 18 karakter, seperti jujur, toleransi, disiplin, hingga cinta tanah air. Dengan kegiatan tersebut, para siswa bisa dijauhkan dari pergaulan yang negatif; (2) Orang tua bisa menjemput anak ke sekolah, khususnya bagi masyarakat yang tinggal di perkotaan, pada umumnya orang tua bekerja hingga pukul 5 sore. Dengan program tersebut, orang tua bisa menjemput anak mereka di sekolah saat pulang kerja; dan (3) Membantu sertifikasi guru artinya membantu guru untuk mendapatkan durasi jam mengajar 24 jam per minggu sebagai syarat mendapatkan sertifikasi guru (Tempo, 2016).

Program kegiatan FDS telah dilaksanakan oleh SMKN 13 Kota Malang selama bertahun-tahun. SMKN 13 Kota Malang yang berbasis taruna ini selalu mengedepankan kedisiplinan, keuletan, dan kerja keras. SMK merupakan sekolah yang selalu menyiapkan lulusannya untuk masuk pada dunia kerja seperti industri, rumah sakit, dan UMKM. Akan tetapi semua upaya tersebut tidak terjadi begitu saja. SMKN tersebut telah menjalin kerja sama dengan TNI Angkatan Laut Kota Malang untuk membina dan menggembleng insan taruna keperawatanmenjadi pribadi yang berkarakter mulia dan berkualitas ketika berada di masyarakat. Tujuan jangka panjang dari kegiatan FDS di SMK tersebut sesuai dengan cita-cita Indonesia di tahun 2045. Di mana pada era tersebut, diharapkan telah diperoleh atau dihasilkan generasi emas bangsa yang memiliki sikap, perilaku, karakter dan jiwa kepemimpinan yang baik (Rokhman et al, 2013).

$$
\text { Howard (2004) menyebut }
$$
pendidikan karakter merupakan upaya mempersiapkan individu untuk beretiket, menilai diri sendiri, dan bertindak untuk melakukan apa harus dilakukan terhadap orang lain. Proses pembinaan karakter dalam FDS ditampilkan pada Gambar 1.
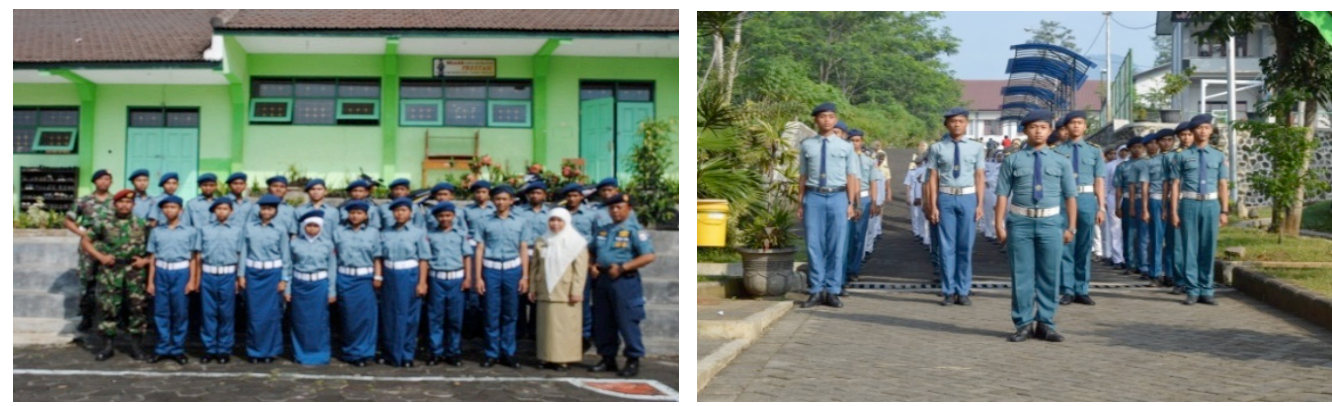

Gambar 1. Pembinaan karakter taruna jurusan keperawatan

Pelaksanaan pembinaan karakter meliputi (1) Pelaksanaan peraturan baris-berbaris (PBB); (2) Aspek-aspek bela negara (PPBN); (3) Kedisiplinan taruna; dan (4) Kepemimpinan (leadership).Berdasarkan penjelasan di atas, tidak dapat dipungkiri bahwa di sekolah tidak hanya cukup dikembangkan aspek akademik pada diri pebelajar saja, tetapi juga aspek moral. Perubahan perilaku peserta didik merupakansalah satu aspek yang perlu diperhatikan guru. Watson (2010) menjelaskan bahwa siswa dipandang secara alamiah sebagai papan tulis yang kosong yang akan dibentuk melalui penguatan untuk menjadi pelajar danwarga negara yang produktif. Oleh karena itu, tugas pendidikan bukan hanya terarah untukmengembangkan aspek kognitif, tetapi juga aspek afektif khususnya karakter.

Adapun bentuk pendidikan karakter yang diimplementasikan hendaknya merupakan pendidikan karakter yang komprehensif. Pendidikan karakter yang komprehensif dijelaskan dalam 11 prinsip sebagai berikut: (1) mempromosikan nilai-nilai etika inti sebagai dasar karakter yang baik; (2) mendefinisikan karakter secara komprehensif dengan memasukkan 
unsur berpikir, merasa,dan perilaku; (3) menggunakan pendekatan yang komprehensif, proaktif,dan efektif untuk pengembangan karakter;

menciptakan kepedulian komunitas sekolah; (5) memberikan kesempatan kepada peserta didikuntuk mempraktekkan tindakan moral; (6) memasukkan kurikulum akademik yang bermakna dan menantang yang menghormati semua peserta didik,mengembangkan karakter mereka, dan membantu mereka untuk sukses; (7) berusaha untuk memotivasi diri siswa; (8) melibatkan staf sekolah dalam pembelajaran dan komunitas moral yang bertanggung jawab dalam pendidikan karakter dan upaya untuk mematuhi nilai-nilai inti yang sama dalam membimbing pendidikan siswa; (9) memupuk kepemimpinan moral bersama dan mendukung inisiatif pendidikan karakter dalam jangka panjang; (10) melibatkan keluarga dan anggota masyarakat sebagai mitra dalam upaya pembangunan karakter; mengevaluasi karakter sekolah, fungsi staf sekolah sebagai karakter, dan sejauh mana siswa memanifestasikan karakter yang baik (Glaze \& Milson, 2006).

Penelitian ini bertujuan untuk mendeskripsikan pembinaan dan pembentukan karakter peserta didik (taruna) jurusan keperawatan di SMK Negeri 13 Malang. Informasi tersebut diharapkan akan berguna bagi sekolah lain pada jenjang pendidikan apapun untuk mempersiapkan, serta memberikan perhatian dalam pembentukan karakter peserta didik melalui kegiatan FDS.

\section{METODE}

Penelitian deskriptif ini bertujuan untuk menggambarkan, mengungkap, dan menjelaskan program FDS dalam membentuk karakter siswa SMKN 13 Kota Malang yang beintegritas. Penentuan subjek penelitian menggunakan teknik purposive sampling, dengan kriteria orang-orang yang mengetahui, berpengalaman, dan dapat memberikan informasi mengenai penanaman nilai-nilai karakter sekaligus sebagai pelaku pendidikan di SMKN 13 Kota Malang. Mereka yang terlibat dalam penelitian ini antara lain kepala sekolah, pembina ekstarkurikuluer terdiri dari guru dan anggota TNI AL Kota Malang (Intruktur), dan peserta didik kelas $\mathrm{X}$ jurusan keperawatan.

Populasi dalam penelitian ini adalah kepala sekolah, guru, dan taruna SMKN 13 Kota Malang sebanyak 120 orang. Adapun sampel yang digunakan sejumlah 90 taruna, guru ekstrakurikuler (guru pembinadan anggota TNI AL) dan kepala sekolah. Data dianalisis secara deskriptif agar memberi makna yang sebenarnya.

\section{HASIL DAN PEMBAHASAN \\ Hasil}

Berdasarkan penelitian yang dilakukan terkait dengan FDS membentuk karakter siswa di SMK 13 Kota Malang yang berintegritas, maka dapat dipaparkan data-data hasil penelitian sebagai berikut.

Pada tahapan ini, penelitian dilaksanakan pada pihak sekolah diantaranya Kepala Sekolah (KS), Guru Pembina Ekstrakurikuler (GPE) dan Guru Pelaksana (TNI AL) dan hasil respon sekolah untuk kegiatan ini ditunjukkan pada Gambar 2. 


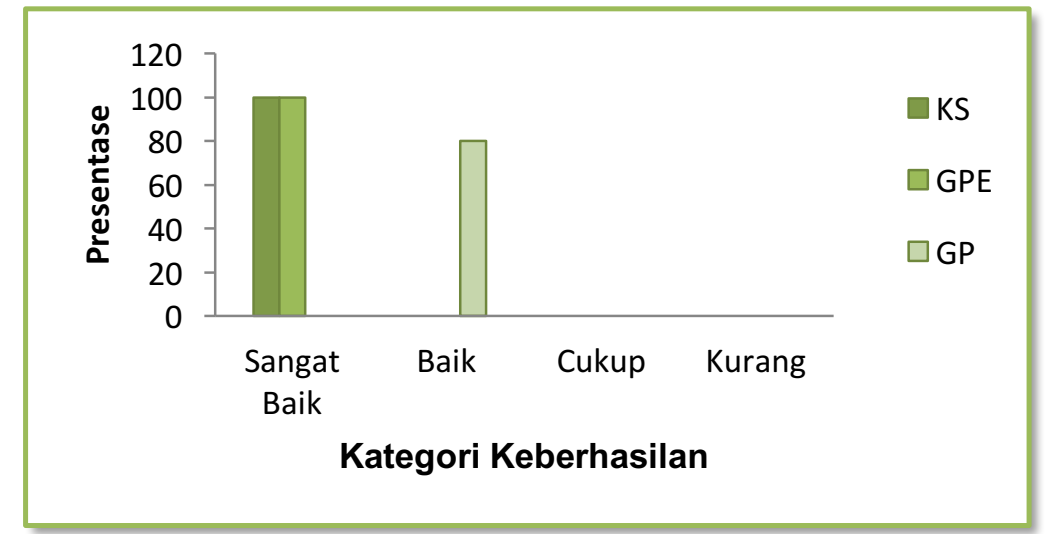

Gambar 2. Respons sekolah terhadap pelaksanaan program FDS

Berdasarkan data di atas KS dan GPE termasuk dalam kategori sangat baik dengan perolehan nilai $100 \%$, dan GP termasuk dalam kategori baik dengan perolehan nilai $80 \%$. Hal ini menunjukkan bahwa komponen penyelenggara kegiatan FDS (Kepala Sekolah, Guru pembina ekstrakulikuler, dan guru pembina (STAF TNI AL) meresponi kegiatan ini dengan sangat baik. Oleh karena itu program ini dilaksanakan secara terus-menerus pada setiap tahun pelajaran.

Data nilai karakter peserta didik jurusan keperawatan pada program FDS sebagaimana yang ditampilkan pada Tabel 1.

Tabel 1. Kualifikasi penilaian karakter peserta didik melaluiFDS

\begin{tabular}{ccccc}
\hline $\begin{array}{c}\text { Tingkat } \\
\text { Penguasaan }\end{array}$ & Kriteria & Frekuensi & $\begin{array}{c}\text { Persentase } \\
\text { Pencapaian }\end{array}$ & Kualifikasi \\
\hline $90-100$ & A & 8 & 8,89 & Memuaskan \\
$80-89$ & B+ & 10 & 11,11 & Sangat Baik \\
$70-79$ & B & 25 & 27,78 & Baik \\
$60-69$ & B- & 47 & 52,22 & Cukup Baik \\
$<60$ & C & - & - & Kurang Baik \\
\hline Jumlah & & 90 & 100 & \\
\hline
\end{tabular}

Tabel 1 menunjukkan bahwa sebanyak 8 orang siswa $(8,89 \%)$ kualifikasi memuaskan, 10 orang siswa $(11,11 \%)$ kualifikasi sangat baik, 25 orang siswa $(27,78)$ kualifikasi baik dan 47 orang siswa $(52,22 \%)$ kualifikasi cukup baik. Hal ini berarti bahwa seluruh siswa berada pada kualifikasi cukup baik hingga memuaskan.

\section{PEMBAHASAN}

\section{Penerapan FDS pada SMKN 13 Kota Malang}

$$
\text { Upaya }
$$

mengembangkan

pendidikan karakter yang efektif dimulai dengan penekanan institusi sekolah dalam mempromosikan pembangunan pendidikan karakter. Proses tersebut mengedepankan pada unsur esensial, diantaranya penguatan misi sekolah sebagai identitas kelembagaan yang mempromosikan pendidikan karakter. Sederhananya sekolah memiliki pernyataan otentik berupa misi dan visi sebagai arah untuk menggarisbawahi pentingnya pengembangan pendidikan karakter di sekolah. Originalitas tersebut bergantung pada alokasi sumber daya, kinerja guru dan proses evaluasinya, serta pemodelan yang tercipta dalam komunitas sekolah sebagai pelaku pendidikan karakter (Berkowitz \& Hoppe, 2009). Kepala sekolah sebagai pucuk pimpinan di sekolah ini mengambil peran yang cukup besar dalam mewujudkan tanggung jawab pembentukan karakter peserta didik yang lebih baik. Menyadari akan hal ini, pimpinan sekolah beserta para staf guru merundingkan visi dan misi sekolah. Adapun visi SMKN 13 yakniunggul spiritual, iptek berbudaya nusantara, berwawasan global. Misi 
sekolah yang sangat terkait erat dengan pembentukan karakter peserta didikantara lain: 1) membekali taruna taruni dengan keimanan dan ketaqwaan padaTuhan yang maha esa, 2) mengembangkan potensi spiritual taruna-taruni, 3) teladan dalam pembentukan karakter, 4) meningkatkan sikap cinta tanah air khususnya pada almamater.

Pendidikan karakter di SMKN 13 Kota Malang dilaksanakan dalam FDS. Implementasi secara bertahap dilakukan sejak pelaksanaan kurikulum KTSP tahun 2006. Di sekolah ini, peserta didik disebut sebagai taruna-taruni. Materi pembinaan ketarunaan sesuai Permendiknas No 39 tahun 2008 mencakup 10 komponen pokok yakni: 1) pembinaan ketakwaan terhadap Tuhan yang Maha Esa, 2) pembinaan budi luhur atau akhlak mulia, 2) pembinaan kepribadian unggul, wawasan kebangsaan, dan bela negara, 3) pembinaan prestasi akademik, seni, dan/atau olah raga sesuai bakat dan minat, 4) pembinaan demokrasi, hak asasi manusia, pendidikan politik, lingkungan hidup, kepekaan dan toleransi sosial dalam konteks masyarakat plural, 5) pembinaan kreativitas keterampilaan dan kewirausahaan, 6) pembinaan kualitas jasmani, kesehatan dan gizi berbasis sumber gizi yang terdiversifikasi, 7) pembinaan sastra dan budaya, 8) pembinaan teknologi informasi dan komunikasi (TIK), serta 9) pembinaan komunikasi dalam bahasa inggris.

Program keperawatan sebagai salah satu jurusan yang dibuka pada sekolah kejuruan ini. Dalam mewujudkan program pembinaan karakter peserta didik, pihak sekolah bekerja sama dengan LANTAMAL V Kota Malang. Sekolah yang berbasis taruna ini selalu mengedepankan kedisiplinan, keuletan, dan loyal terhadap tugas yang diberikan. Pembinaan karakter taruna merupakan upaya dalam rangka menyiapkan taruna menjadi manusia yang bermoral dan berakhlak mulia, sopan, dan saling menghargai di lingkungan sekolah maupun masyarakat. Para taruna selain mendapatkan pengetahuan yang memperkuat kognisi, afeksi, dan keterampilan mereka juga melakukan kegiatan ekstrakurikuler dalam FDS. Kegiatan tersebut antara lain barisberbaris (PBB), pendidikan pendahuluan bela negara (PPBN), kedisiplinan taruna, dan kepemimpinan (leadership) yang difokuskan pada semester 1. Sementara pada semester 2, kegiatan FDS mencakup pada domain cara memberi instruksi, SAR, Samapta dan Garjas, serta upacara sipil. Khusus untuk kegiatan FDS yang disebutkan inidilaksanakan setiap hari Rabu dan Kamis pada pukul 15.00-17.00 WIB. Di samping itu, masih banyak lagi kegiatan FDS lainnya yang terkait dengan pembinaan keterampilan peserta didik terkait dengan jurusan yang diminati siswa, namun pada bagian ini tidak dipaparkan lebih detail. Demikian juga kegiatan lainnya yang berhubungan dengan pembinaan minat dalam bidang olahraga dan seni.

FDS dilakukan guna membentuk dan mengembangkan karakter para taruna. Program FDS secara spesifik mengarah pada penanaman nilai-nilai nilai-nilai etika inti (seperti ketekunan, kasih sayang, integritas, dan keadilan) yang mendorong siswa untukproduktif, bertindak adil, dan menjadi warga masyarakat demokratis. Ketika mereka tumbuh dalam karakter, mereka pasti tumbuh dalam kapasitas dan komitmen untuk melakukan pekerjaan terbaik, melakukan hal yang benar, dan menjalani kehidupan dengan tujuan yang jelas. Pendidikan karakter yang dilaksanakan pada SMKN 13 Kota Malang efektif melibatkan berbagai jurusan bukan hanya keperawatan saja, serta melibatkan lingkungan sekolah yang memungkinkan semua peserta didik, tanpa terkecuali, untuk mewujudkan potensi mereka dalam mencapai tujuan-tujuan penting.

\section{Dampak FDS pada Karakter Taruna}

Pendidikan karakter memiliki makna yang lebih tinggi daripada pendidikan moral, karena pendidikan karakter menanamkan kebiasaan tentang hal yang baik. Dampaknya bukan hanya terbatas pada pembentukan pemahaman peserta didik tentang nilai moral yang baik serta 
benar, melainkan menjadi pelaku perwujudan karakter hidup yang baik. Diharapkan proses ini dapat memberi pola kehidupan dan terus-menerus dipraktekkan dalam kehidupan modern.

Dampak FDS tersebut dapat dicermati dalam konteks karakteristik taruna SMKN 13 Kota Malang. Peserta didik pada SMK tersebut bukan hanya berasal dari wilayah Pulau Jawa dan sekitarnya, yang lebih dikenal santun dalam berbicara. SMK ini juga dipercayakan menangani siswa dari wilayah NTT dan Papua melalui program afirmasi. Latar belakang peserta didik dari wilayah tersebut cenderung berkarakter kasar, mudah terbakar emosional, serta gampang terprovokasi untuk melakukan tindakan-tindakan yang merugikan orang lain. Sebut saja, beberapa peserta didik asal Papua yang berasal dari suku yang berbeda-beda, mudah sekali tersinggung karena kesalahpahaman kecil dan berujung pada konflik antar suku, meskipun kini mereka berada jauh dari wilayah asalnya. Sebagian siswa lainnya saat pertama kali masuk SMK ini memiliki penampakan yang lisut dan layu, mungkin karena latar belakang ekonomi keluarga yang kurang mendukung. Dalam perjalanan waktu, setelah ditempa dengan program FDS berbasis ketarunaan, kini para taruna mengalami perubahan bukan saja secara fisik tetapi juga secara spiritual. Penampakan fisik menunjukkan jati diri mereka sebagai taruna sejati. Secara spritual terbentuk karakter taruna yang disiplin, jujur, tangguh, bekerja keras, berjiwa ksatria, rela berkorban, serta bertanggung jawab.

Sebagian taruna yang tinggal jauh dari lokasi sekolah menempati asrama yang terletak di dalam lokasi sekolah, termasuk taruna asal NTT dan Papua. Kehidupan di asrama ditangani oleh ibu asrama, sehingga asrama pun menjadi komunitas belajar otentik dalam pembentukan karakter. Sejumlah taruna asal Papua misalnya yang hidup cenderung terkotak-kotak, memiliki emosional yang kurang stabil, serta mudah terprovokasi untuk melakukan konflik, kini sangat merasakan kehidupan yang sangat berbeda dengan di wilayah asalnya. Mereka bukan hanya belajar untuk memahami sisi kognitif dari karakter, melainkan juga dibimbing untuk berkarakter yang benar. Mereka melihat dan langsung mengalami bagaimana karakter itu dimodelkan oleh guru-guru yang ramah dan berkarakter mulia. Kini mereka bahkan sangat menyadari bahwa konflik horizontal sangat tidak berguna. Konflik hanya memberikan ruang bagi terciptanya kekerasan baik secara fisik maupun psikis. Praktek kekerasan tersebut selain dialami oleh mereka di rumah, di lingkungan/komunitas tempat tinggalnya, dan di sekolah. Hal ini senada dengan pendapat Leasa \& Samallo (2014) bahwa praktek kekerasan masih dilakukan oleh guru di sekolah, serta berdampak pada motivasi khususnya minat dan perhatian peserta didik dalam belajar. Kini para taruna asal Papua tersebut bahkan telah mengikuti berbagai program pertukaran pelajar di Negeri Thailand, serta bertekad untuk kembali dan membangun wilayah Papua dalam keharmonisan dan kedamaian menuju kejayaan.

Terbentuknya karakter yang unggul mendorong para taruna berprestasi secara akademik. Taruna dengan karakter yang kokoh pasti memiliki prestasi belajar lebih baik, dibandingkan dengan taruna yang berkarakter jelek. Dengan demikian program FDS memberikan dampak positif pada sekolah dan peserta didik khususnya taruna jurusan keperawatan dimana pola hidup lebih tertata, kecerdasan emosional lebih baik, terbentuk kedisiplinan dalam belajar sehinggaberdampak positif pada prestasi akademik. Berdasarkan hasil wawancara dengan para guru, diperoleh informasi bahwa prestasi akademik para taruna mengalami kenaikan signifikan dibandingkan dengan kondisi sebelumnya.

\section{Respon Siswa Terhadap Program FDS Pembinaan Karakter}

SMKN 13 Kota Malang merupakan salah satu SMK unggulan di Kota Malang dengan kegiatan sehari-hari yaitu pembinaan karakter bagi para taruna jurusan THP, Keperawatan dan 
Nautika. Program pembinaan ini dilaksanakan oleh pihan TNI AL yang mengedepankan kedisiplinan, dan keuletan bagi para tarunanya. SMK 13 Kota Malang banyak menerima lulusan SMP/MA dari berbagai wilayah Indonesia (Papua, NTT, Jawa, dll) untuk dilatih menjadi taruna yang berkarakter. Respon sekolah berkaitan dengan kegiatan ekstrakurikuler ini sangat positif. Respon sekolah terkait dengan kegiatan ini adalah sekolah sebagai pusat pembelajaran yang mencerdaskan anak bangsa harus menjadi pilar utama. Melihat perkembangan yang ada banyak sekali peserta didik yang berperilaku buruk kepada gurunya dan menjadi rusak di lingkungan tempat tinggalnya.Mereka mempertotonkan perilaku-perilaku negatif misalnya narkoba, tawuran, dan pemerkosaan dimana-mana. Oleh karena itu guru sebagai staf pengajar, memiliki fungsi utama untuk melakukan bimbingan dan melaksanakan program yang dijalankan oleh pihak sekolah, selain itu kepala sekolah harus bertanggungjawab terhadap program yang dilaksanakan (Taub, 2015).

Selama program ini berjalan terus maka evaluasi antar lembaga pendidikan sangat penting untuk mengembangkan kurikulum yang secara eksplisit mencakup pendidikan karakter. Menyadari bahwa karakter individu tidak dapat dibentuk hanya melalui satu atau dua kegiatan saja, maka sekolah menyiapkan rancangan program pembangunan berkelanjutan dan karakter yang terintegrasi dalam pembelajaran. Semua proses ini juga melibatkan semua guru, staf, dan lembaga lainnya di lingkungan pendidikan, sehingga manfaat dari pembangunan karakter dapat dirasakan (Kamaruddin, 2012).

\section{Penilaian Karakter Program FDS Jurusan Keperawatan}

Penilaian dalam pembinaan karakter itu sangat penting agar menjadi skala prioritas dalam menggambarkan ukuran karakter para taruna. Jika tidak menggunakan skala faktor penilaian yang baku maka penilaian dilakukan secara tidak adil dan terstandar, sesuai dengan keinginan guru. Penilaian karakter para taruna jurusan keperawatan berada dalam kategori cukup baik. Hal ini akan cenderung meningkat jika para taruna cenderung menanamkan jiwa karakter yang baik secara terus-menerus. Hal ini diduga karena para taruna mengalami perubahan status dari siswa SMP ke SMK sehingga turut mempengaruhi psikologi mereka. Faktor yang paling ekstrim juga adalah jiwa kepemimpinan yang masih rendah karena para tarunaberasal dari latar belakang keluarga sipil dengan kondisi ekonomi cukup bahkan rendah, sehingga turut mempengaruhi pola pendidikan keluarga. Di samping itu, sebagian taruna berasal dari wilayah timur, yang kondisi emosional dan kehidupan sosialnya mudah mudah tergoyahkan.

Faktor internal lain cenderung berpengaruh berasal dalam diri individu itu sendiri baik yang bersifat fisik maupun psikis. Faktor internal yang berpengaruh terhadap perilaku yaitu harga diri (self esteem) dan faktor kepandaian atau kecerdasan (intelligence). Faktor internal meliputi hal-hal sebagai berikut. Pertama Kematangan, yang merupakan perkembangan susunan syaraf sehingga misalnya fungsi-fungsi indera menjadi lebih sempurna. Kedua faktor pengalaman, yaitu hubungan timbal balik dengan lingkungannya. Ketiga faktor transmisi sosial, yaitu hubungan timbal balik dengan lingkungan sosial, antara lain melalui pengasuhan dan pendidikan dari orang lain. Faktor keempat ekuilibrasi, yaitu sistem pengaturan dalam diri peserta didik itu sendiri yang mampu mempertahankan keseimbangan dan penyesuaian diri terhadap lingkungannya (Mustaqim et al, 2013).

Jurusan keperawatan menyiapkan peserta didiksiap terjun di dunia kerja. Mereka akan berkarya di rumah sakit, puskesmas, serta klinik. Maka peserta didik tersebut harus memiliki karakter dan integritas yang baik, teristimewa jika bertemu dengan pasien yang memiliki corak sosial, pandangan hidup, dan karakter yang berbeda dengan mereka. 
Maka mereka perlu disiapkan secara matang dengan karakter serta kepribadian yang luhur untuk melayani orang lain. Karakter berkaitan dengan moral dari diri seseorang. Peserta didik yang memiliki karakter yang baik, cenderung memiliki nilai moral dan estetika yang baik. Pentingnya aturanataunorma dalam pelaksanan pendidikan karakter dikemukakan oleh Nucci \& Navaes (2008) bahwa dalam pendidikan moral perlu melibatkan dukungan otoritas norma. Otoritas norma dalam hal ini dimaknai bahwa aturanaturan dalam pelaksanaan pendidikan karakter tentunya berupa pedoman tentang perilaku-perilaku yang harus dilakukan oleh peserta didik.

\section{SIMPULAN DAN SARAN}

Berdasarkan hasil penelitian, maka dapat disimpulkan bahwa respon sekolah terhadap program FDS dalam pembinaan karakter peserta didik yang berintegritas memiliki respon yang sangat postif. Program ini dinilai sangat bermanfaat dalam menanamkan hal-hal baik kepada peserta didik agar menjadi generasi emas bangsa yang berintegritas di lingkungan masyarakat. Oleh karena itu sekolah perlu terus mengembangkan kegiatan FDS sehingga memperkuat penanaman nilainilai karakter dan akhlak mulia bagi peserta didik.

Hasil presentasi nilai karakter siswa masih dalam kategeri cukup baik dikarenakan sekolah dengan memiliki siswa yang bercorak suku, budaya, latar belakang ekonomi, sosial, dan kepribadian yang berbeda yang mempengaruhi nilai karakter peserta didik. Melalui FDS terbentuk penampakan fisik dan psikis yang tangguh. Penampakan fisik menunjukkan jati diri mereka sebagai taruna sejati. Secara spritual/psikis terbentuk karakter taruna yang disiplin, jujur, tangguh, bekerja keras, berjiwa ksatria, rela berkorban, serta bertanggung jawab. Nilai-nilai karakter ini berdampak positif terhadap pencapaian kinerja akademik yang lebih baik. Selanjutnya diperlukan untuk mengkaji dampak program FDS terhadap motivasi dan prestasi belajar peserta didik, termasuk peserta didik program afirmasi dan inklusi. Penelitian selanjutnya juga disarankan untuk memperoleh informasi tentang output karakter lulusan di dunia kerja atau di masyarakat.

\section{UCAPAN TERIMA KASIH}

Ucapan terimakasih kepadaTuhan yang maha kuasa atas berkat dan tuntunan, penelitian dan penulisan artikel ini dapat berlangsung dengan baik. Selanjutnya kepada Kepala Sekolah dan civitas SMKN 13 Kota Malang berpartisipasi aktif memberikan informasi dan masukani selama penelitian.

\section{DAFTAR PUSTAKA}

Agboola, A. \& Tsai, K. C. 2012. Bring Character Education into Classroom. European Journal of Educational Research, 1 (2), hlm. 163-170.

Berkowitz, M. W.\& Hoppe, M. A. 2009. Character Education And Gifted

Children.High Ability Studies, 20 (2): 131-142.

Budimansyah, D.\& Sapriya. 2012. Refleksi Implementasi Project Citizen dalam Pembelajaran Pendidikan Kewarganegaraan di Indonesia. Dalam Budimasyah, D. (Penyuting). Dimensi-dimensi parktik pendidikan karakter. Bandung: Widya Aksara Pers.

Glanzer, P. L. \& Milson, A. J. 2006.Legislating theGood: aSurvey and Evaluation of Character Education Laws in the United States. Educational Policy, 20 (3), hlm.525-550.

Hogan, P. 2006. Education as a Discipline of Thought and Action: A Memorial to John Wilson. Oxford Review of Education, 32(2), hlm. 253-264.

Howard, R. W, Berkowitz. M.W \& Schaeffer. Politics of Character Education. Educational Policy. 18 (1): 188-125.

Istyarini, R. B. K. 2015. Character Education Development Modelbased E-Learning and Multiple in Telegency in Childhood in Central Java. Global Journal of Computer 
Science and Technology, XV (1), hlm. 1-11.

Kamaruddin, S. A. 2012. Character Education and Students Social Behavior, Journal of Education and Learning, 6 (4), hlm. 223-230.

Koesoema A, Doni. 2007. Pendidikan Karakter Strategi Mendidik Anak di Zaman Global. Jakarta: Gramedia Widiasarana Indonesia.

Leasa, M., \& Samallo, R. 2014. Learning Motivation of Students in Ambon Child-Friendly School, Moluccas. Education, 4(2): 41-51.

Nucci, L. P.\& Navaez, D. 2008. Handbook of Moral and Character Education. New York: Routledge.

Mustaqim, W., Ali, M., Mustaqin.\& Ismara, I. 2013. Pengaruh Penerapan Pendidikan Karakter di Sekolah Terhadap Perilaku Akademik Siswa Kelas XI Teknik Komputer Jaringan di SMK Piri 1 Yogyakarta.Jurnal Skripsi, hlm. 110.

Qoyyimah, U. 2016. Inculcating Character Education Through EFL Teaching in Indonesian State Schools. Pedagogies: An International Journal, 11 (2), hlm. 1-18.

Rokhman, F., Hum, M., Syaifudin, A. \&Yuliati. 2013. Character Education For Golden Generation 2045 (National Character Building for Indonesian Golden Years).
Procedia-Social and Behavioral Sciences. 141, hlm. 1161-1165.

Sultana, N. 2008. Promoting Social Skills and Character Building through Classroom Instruction. The International Journal of the Humanities, 6 (2), hlm. 151-162.

Taub, R. 2015. A New Educational Reform in Israeli High Schools Affecting Teachers' Motivation and Perception of the Teaching Profession. Procedia - Social and Behavioral Sciences, 209: 503 508.

Tempo. 28 Juli 2016. Full Day School, hlm. 1.

Undang-Undang RI No. 20 Tahun 2003. Sistem Pendidikan Nasional. Kementerian Riset, Teknologi dan Pendidikan Tinggi Republik Indonesia, dari http://sumberdaya.ristekdikti.go.id,di unduh 03 Oktober 2016.

Watson, M. 2008. Developmental Discipline and Moral Education. Dalam Nucci, LP., Narvaez, D. (Penyunting). Handbook of and Character. New York: Routledge.

Winton, S. (2008). The Appeal(s) of Character Education in Threatening Times: Caring and Critical Democratic Responses. Comparative Education, 44(3), hlm. 305-316. 